\title{
Isolation and Characterization of Phages Infecting Bacillus subtilis
}

\author{
Anna Krasowska, ${ }^{1}$ Anna Biegalska, ${ }^{1}$ Daria Augustyniak, ${ }^{2}$ Marcin Loś,,${ }^{3,4,5}$ \\ Malwina Richert, ${ }^{6}$ and Marcin Lukaszewicz ${ }^{1}$ \\ ${ }^{1}$ Department of Biotransformation, Faculty of Biotechnology, University of Wroclaw, Fryderyka Joliot-Curie 14a, \\ 50-383 Wroclaw, Poland \\ ${ }^{2}$ Department of Pathogen Biology and Immunology, Institute of Genetics and Microbiology, University of Wroclaw, \\ Przybyszewskiego 63-77, 51-148 Wroclaw, Poland \\ ${ }^{3}$ Department of Molecular Biology, University of Gdańsk, Kładki 24, 80-822 Gdańsk, Poland \\ ${ }^{4}$ Institute of Physical Chemistry, Polish Academy of Sciences, Kasprzaka 44/52, 01-224 Warsaw, Poland \\ ${ }^{5}$ Phage Consultants, Tenisowa 10/5, 80-180 Gdańsk, Poland \\ ${ }^{6}$ Laboratory of Electron Microscopy, Faculty of Biology, University of Gdańsk, Kładki 24, 80-822 Gdańsk, Poland
}

Correspondence should be addressed to Marcin Łukaszewicz; marcin.lukaszewicz@uni.wroc.pl

Received 6 July 2014; Revised 15 September 2014; Accepted 25 September 2014

Academic Editor: Dimitrios Karpouzas

Copyright ( 2015 Anna Krasowska et al. This is an open access article distributed under the Creative Commons Attribution License, which permits unrestricted use, distribution, and reproduction in any medium, provided the original work is properly cited.

\begin{abstract}
Bacteriophages have been suggested as an alternative approach to reduce the amount of pathogens in various applications. Bacteriophages of various specificity and virulence were isolated as a means of controlling food-borne pathogens. We studied the interaction of bacteriophages with Bacillus species, which are very often persistent in industrial applications such as food production due to their antibiotic resistance and spore formation. A comparative study using electron microscopy, PFGE, and SDS-PAGE as well as determination of host range, $\mathrm{pH}$ and temperature resistance, adsorption rate, latent time, and phage burst size was performed on three phages of the Myoviridae family and one phage of the Siphoviridae family which infected Bacillus subtilis strains. The phages are morphologically different and characterized by icosahedral heads and contractile (SIO, , SUB $\omega$, and SPO $\sigma$ phages) or noncontractile (AR $\pi$ phage) tails. The genomes of SIOФ and SUB $\omega$ are composed of $154 \mathrm{~kb}$. The capsid of SIOФ is composed of four proteins. Bacteriophages SPO $\sigma$ and $\mathrm{AR} \pi$ have genome sizes of $25 \mathrm{kbp}$ and $40 \mathrm{kbp}$, respectively. Both phages as well as SUB $\omega$ phage have 14 proteins in their capsids. Phages SIO $\Phi$ and SPO $\sigma$ are resistant to high temperatures and to the acid (4.0) and alkaline (9.0 and 10.0) $\mathrm{pH}$.
\end{abstract}

\section{Introduction}

Recent investigations show that bacteriophages could be used as a means of controlling food-borne pathogens [1-3]. New phages are therefore being isolated and characterized $[4,5]$. One of the bacterial genera with the highest prevalence in food industry, which could potentially be controlled by bacteriophages, is Bacillus, which belong to the heterogeneous group of Gram-positive, endospore-forming, facultative anaerobic bacteria [6,7]. Despite the numerous advantages of Bacillus species in industry applications, they may also cause damage. The pathogenicity of Bacillus anthracis for mammals is well known, and other Bacillus species infections have been documented since the beginning of the last century $[8,9]$. Bacillus cereus is considered a pathogenic species causing local infections, bacteremia, septicemia endocarditis and pericarditis, and infection of the central nervous system and respiratory tract [10-15]. Bacillus cereus is the main factor in food poisoning resulting from toxin production [16]. Beside the well-known pathogenic Bacillus species, recent studies have detected the production of enterotoxins and emetic toxin by B. subtilis, B. pumilus, and B. licheniformis, resulting in food-borne illnesses [17-19]. Bacillus subtilis contaminated $25 \%$ of samples of food products in The Netherlands (milk, yeast, flour, pasta products, cocoa, chocolate, bakery products, meat products, herbs, and spices) [20] and $12 \%$ of raw 
TABLE 1: Bacillus subtilis strains and bacteriophages.

\begin{tabular}{|c|c|c|c|c|c|c|}
\hline \multirow{2}{*}{ Number } & \multirow{2}{*}{ Strain } & \multirow{2}{*}{ Origin } & \multicolumn{4}{|c|}{ Bacteriophage typing } \\
\hline & & & $\mathrm{SUB} \omega$ & $\mathrm{SPO} \sigma$ & $\operatorname{SIO\Phi }$ & $\mathrm{AR} \pi$ \\
\hline 1 & B. subtilis ATCC 6633 & Polish Academy of Sciences, Wroclaw & + & + & - & - \\
\hline 2 & B. subtilis 168 & \multirow{2}{*}{ Institute, Rijksuniversiteit Groningen, Holland } & 0 & + & 0 & 0 \\
\hline 3 & B. subtilis SWV215 & & + & + & - & - \\
\hline 4 & B. subtilis 10 & University of Wroclaw, Faculty of Biotechnology & - & - & + & - \\
\hline 5 & B. subtilis $\mathrm{B} 3$ & \multirow{10}{*}{$\begin{array}{l}\text { Wroclaw University of Environmental and Life } \\
\text { Sciences, Faculty of Food Science }\end{array}$} & + & + & - & + \\
\hline 6 & B. subtilis Ż7-mutant B3 & & + & + & - & + \\
\hline 7 & B. subtilis Ż17-mutant B3 & & + & + & - & + \\
\hline 8 & B. subtilis Ż25-mutant B3 & & + & + & - & + \\
\hline 9 & B. subtilis Hb36-mutant B3 & & + & + & - & + \\
\hline 10 & B. subtilis $\mathrm{B} 20$ & & 0 & + & - & 0 \\
\hline 11 & B. subtilis $\mathrm{P} 22$ & & + & + & - & + \\
\hline 12 & B. subtilis KT20 & & 0 & - & 0 & 0 \\
\hline 13 & B. subtilis 172 & & + & + & - & + \\
\hline 14 & B. subtilis $\mathrm{B} 24$ & & 0 & + & - & 0 \\
\hline 15 & B. subtilis PCM1938 & \multirow{6}{*}{ Polish Academy of Sciences, Wroclaw } & + & + & - & - \\
\hline 16 & B. subtilis PCM 2226 & & + & + & + & - \\
\hline 17 & B. subtilis PCM 486 & & 0 & + & - & 0 \\
\hline 18 & B. subtilis PCM 2189 & & + & + & - & - \\
\hline 19 & B. subtilis PCM 2005 & & + & + & - & 0 \\
\hline 20 & B. subtilis PCM 2224 & & + & + & - & - \\
\hline
\end{tabular}

(-) Plaques not formed, (+) distinct clear plaques, and (0) hazy plaques.

materials, dough and bread samples in South Africa [21]. Moreover, $B$. subtilis spore contamination has been found in wheat flour, ropy bread [22], and gelatin [23].

The removal of Bacillus contamination is limited due to its resistance to physicochemical decontaminations methods. Usually the food industry uses physical methods of sterilization or disinfection such as $u v$, gamma radiation, or high temperature, but, unfortunately, they are often not effective against the highly resistant Bacillus spores [24, 25]. One option for Bacillus contamination treatment could be phagotherapy [26].

Bacteriophages are the largest group of viruses $[27,28]$. They are very useful for people in phage therapy [29]. On the other hand, preventive phage therapy may eliminate pathogenic bacteria from food products. Phages are hostspecific and infect only specific species or strains [1] with a few exceptions [30]. Although investigations have shown that bacteriophages can aid in successful eradications of foodborne pathogens such as Listeria monocytogenes, Escherichia coli, Salmonella typhimurium, or Campylobacter [1,31], there are few commercial products, such as LISTEX P100, which have received the GRAS status [32]. Thus, it is necessary to determine the criteria for the application of phages in the control of bacteria in food and therefore all newly isolated phages with the potential application in antibacterial therapy should be characterized in detail. Beside using isolated phages as decontamination agents, they could be used in bacterial detection and serotyping or strain improvement recently described by Petty et al. [33]. However, the commercial application of bacteriophages requires the optimization of culture conditions and detailed determination of the physical and chemical factors influencing phage viability $[34,35]$. The first attempts to control Bacillus subtilis infections by phages were carried out by Ackermann et al. [36]. The results showed an extreme heterogeneity of $B$. subtilis strains. Ackermann's phagotype system was used by Inatsu et al. [37] for the differentiation of B. subtilis (natto) and other B. subtilis strains isolated from fermented soybean foods [38].

The aim of this work was to isolate and characterize Bacillus bacteriophages in view of their potential application in phagotyping, strain improvement, and eradication of unwanted Bacillus strains in food industries. We have isolated four bacteriophages with different specificity to $20 \mathrm{~B}$. subtilis strains. Detailed data on their morphology, thermal and $\mathrm{pH}$ stability, genome size, and capsid protein mass are described for bacteriophages specified for four representative B. subtilis strains.

\section{Materials and Methods}

2.1. Bacillus Strains and Bacteriophages. The origins of bacteriophages used in this study as well as their host strains are shown in Table 1. Bacillus strains 10 (isolated from soil), SWV215 [39], B3 [40], and ATTC6633 [41] were used for detailed investigation (Table 1). Bacillus strains were maintained as frozen stocks at $-80^{\circ} \mathrm{C}$ in $1.5 \%$, nutrient broth (Biocorp, Poland) with $2 \%$ agar-agar (BioShop, Canada Inc) supplemented with $15 \%(\mathrm{v} / \mathrm{v})$ of glycerol. For experiments, 
the strains were cultured on the nutrient agar and then cultured overnight in a liquid nutrient broth. The Bacillus subtilis-specific bacteriophages $\mathrm{SUB} \omega, \mathrm{SPO} \sigma$, SIOФ (Acc. number KC699836), and AR $\pi$ were isolated from soil supplemented with a liter of Bacillus subtilis cultures. After a week, soil samples ( $1 \mathrm{~g}$ ) were suspended in water, shaken (200 rpm/30 $\mathrm{min})$, and centrifuged (4500 rpm/10 min), and the supernatant was filtered through a polyethersulfone (PES) $0.22 \mu \mathrm{m}$ Millipore filter. Phage propagation was performed as follows: $45 \mathrm{~mL}$ of filtered soil samples and $5 \mathrm{~mL}$ culture of Bacillus strain grown overnight in nutrient broth were added to $20 \mathrm{~mL}$ of fresh nutrient broth and incubated for $24 \mathrm{~h}$ at $37^{\circ} \mathrm{C}$. The suspension was centrifuged (4500 rpm/10 min) and the supernatant was filtered through a PES $0.22 \mu \mathrm{m}$ Millipore filter. The bacteriophage titer in the filtrate was assessed using the double-agar layer technique of Adams [42].

Phage stocks were prepared in nutrient broth and then stored at $4^{\circ} \mathrm{C}$.

2.2. Electron Microscopy. A high-titer phage lysate filtered through a PES $0.22 \mu \mathrm{m}$ Millipore filter was centrifuged at $25,000 \times \mathrm{g}$ for $60 \mathrm{~min}$, and the pellet was washed twice in ammonium acetate $(0.1 \mathrm{M}, \mathrm{pH} 7.0)$. A portion of the resuspended sediment was deposited on carbon-coated Formvar films, stained with $1 \%$ uranyl acetate for $30 \mathrm{~s}$, and examined in a Philips CM 100 (Philips CM 100, Japan) transmission electron microscope at $80 \mathrm{kV}$ with $39,000 \mathrm{x}$ magnification. The phage size was determined from the average of five to seven independent measurements using T4 phage tail $(114 \mathrm{~nm})$ as the magnification control.

2.3. Thermal Treatment. The thermal resistance of all bacteriophages was determined at $23,50,60,70,80,90$, and $100^{\circ} \mathrm{C}$ in a temperature-controlled thermo-block (Labnet International. Inc.), at $121^{\circ} \mathrm{C}$ in an autoclave, at $4^{\circ} \mathrm{C}$ and $-20^{\circ} \mathrm{C}$ in a standard refrigerator, and at $-80^{\circ} \mathrm{C}$ in a low temperature freezer (REVCO Sanyo, Japan). Equal volumes of phage $\left(10^{7} \mathrm{pfu} / \mathrm{mL}\right.$ in sterile water $)$ were incubated for 1,2 , $5,10,15,30,60$, and $180 \mathrm{~min}$ at $4^{\circ} \mathrm{C}$ and then placed in an ice bath or thawed. Samples were assayed to determine surviving pfu using the double-agar layer technique [42].

2.4. $\mathrm{pH}$ Treatment. The influence of $\mathrm{pH}$ on the bacteriophages was assayed in CP (citrate-phosphate) buffer $(0.2 \mathrm{M}$ $\mathrm{Na}_{2} \mathrm{HPO}_{4} / 0.1 \mathrm{M}$ citrate) within the $\mathrm{pH}$ range of 2.0 to 8.0 and in carbonate buffer $\left(0.2 \mathrm{M} \mathrm{H}_{2} \mathrm{CO}_{3} / 0.2 \mathrm{M} \mathrm{NaHCO}_{3}\right)$ within the $\mathrm{pH}$ range of 9.0 to 11.0. Experiments were carried out at room temperature $\left(25^{\circ} \mathrm{C}\right)$ for 1 and $6 \mathrm{~h}$. Samples were assayed to determine pfu using the double-agar layer technique [42].

2.5. Host Range Determination. The host range of bacteriophages was assayed according to Yang et al. [43] as follows: $10^{8}$ bacterial cells were mixed with molten $0.6 \%$ agar and the mixture was poured on $2 \%$ solid agar to make double layer agar plates. After solidification, $10 \mu \mathrm{L}$ of bacteriophage $\left(>10^{6} \mathrm{pfu} / \mathrm{mL}\right)$ was spotted on each plate with each of the different Bacillus strains, incubated, and the presence of lysed plates was examined to determine host range.
2.6. Adsorption Rate, Latent Time, and Phage Burst Size. Experiments were performed as described previously [42, 44, $45]$ with slight modifications. Equal volume of phages $\left(10^{6}-\right.$ $10^{7} \mathrm{pfu} / \mathrm{mL}$ ) was added to $0.9 \mathrm{~mL}$ of overnight cultures of host bacterial species and incubated at $37^{\circ} \mathrm{C}$ for $5 \mathrm{~min}$. After incubation, the mixture was diluted to $10^{-5}$ and filtered through a PES $0.22 \mu \mathrm{m}$ Millipore filter. The number of free phages in the filtrate was determined in duplicate, using the double-agar layer method.

To determine the phage latent time and burst size a onestep experiment was carried out according to the previous descriptions [46] with modifications. To $0.9 \mathrm{~mL}$ of overnight cultures of host bacteria was added $0.1 \mathrm{~mL}$ of the bacteriophage suspension. The bacteria were allowed to adsorb the bacteriophages for $5 \mathrm{~min}$ at $37^{\circ} \mathrm{C}$; the mixture was diluted to $10^{-5}$ or $10^{-4}$ and further incubated for $135 \mathrm{~min}$ at $37^{\circ} \mathrm{C}$. Samples were taken at 10 min intervals and phage titer was determined by the double layer-agar plate method. Burst size was calculated as the ratio of the final amount of liberated phage particles to the initial number of infected bacterial cells during the latent period [42].

2.7. Phage DNA Extraction. Phage particles were partially purified by PEG precipitation [47]. High titer suspensions $\left(10^{10} \mathrm{pfu} / \mathrm{mL}\right)$ of filtered phage lysate were mixed with $\mathrm{NaCl}$ ( $1 \mathrm{M}$ final conc.) and incubated on ice for $1.5 \mathrm{~h}$. Then PEG 8000 was added to a final concentration of $10 \%$ and the mixture was incubated on ice for $2.5 \mathrm{~h}$. This was followed by the centrifugation of precipitated phages $\left(10000 \mathrm{~g}, 4^{\circ} \mathrm{C}\right.$, $20 \mathrm{~min}$ ). Pellets were suspended in $10 \mathrm{mM}$ TE buffer ( $\mathrm{pH} 8.0$ ) or TM buffer (10 mM Tris- $\mathrm{HCl}, 100 \mathrm{mM} \mathrm{NaCl}, 10 \mathrm{mM} \mathrm{MgCl}$; $\mathrm{pH}$ 7.4). The residual $\mathrm{PEG}$ and bacterial debris were next removed by gentle extraction for $30 \mathrm{~s}$ with an equal volume of chloroform, followed by centrifugation at $3000 \times \mathrm{g}, 4^{\circ} \mathrm{C}$ for $15 \mathrm{~min}$.

2.8. Pulsed-Field Gel Electrophoresis PFGE. Determination of bacteriophage genome size by PFGE was performed according to Lingohr et al. [48]. Purified phage particles in $10 \mathrm{mM}$ TE buffer ( $\mathrm{pH} 8.0)$ were incorporated in $1: 1$ proportion into $2 \%$ low-melting agarose in $10 \mathrm{mM}$ TE. The solid gel plugs were incubated for $2.5 \mathrm{~h}$ at $54^{\circ} \mathrm{C}$ in $1 \mathrm{~mL}$ of phage lysis buffer containing $50 \mathrm{mM}$ pH 8.0 Tris- $\mathrm{HCl}, 50 \mathrm{mM}$ EDTA, $1 \%(\mathrm{w} / \mathrm{v}) \mathrm{SDS}$, and $100 \mu \mathrm{g} / \mathrm{mL}$ (final conc.) of proteinase $\mathrm{K}$ (phages $\mathrm{SUB} \omega, \mathrm{SPO} \sigma, \mathrm{SIO} \Phi$ ) or $1 \mathrm{mg} / \mathrm{mL}$ of proteinase $\mathrm{K}$ (phage $\mathrm{AR} \pi$ ). The plugs were washed at least 4 times in $10 \mathrm{mM}$ Tris/EDTA buffer (TE, pH 8.0) and pulsed-field gel electrophoresis (PFGE) was performed (Bio-Rad, UK) in 1\% agarose in $0.5 \mathrm{X}$ TBE buffer ( $\mathrm{pH} 8.3$ ). The PFGE parameters were as follows: $0.5 \mathrm{X}$ TBE buffer; $6 \mathrm{~V} / \mathrm{cm}$, initial switch time $1 \mathrm{~s}$; final switch time $15 \mathrm{~s}$; run time $16 \mathrm{~h}$; temperature $12^{\circ} \mathrm{C}$. Gels were stained with ethidium bromide followed by destaining in miliQ water. The genome size was determined with BioRad Quantity One software, using the Low Range PFG marker (New England BioLabs, UK) as a standard.

2.9. Preparation of Phage Structural Proteins and SDS-PAGE. Concentrated phage particles in TM buffer were extracted with chloroform $(1: 1 \mathrm{v} / \mathrm{v})$ and, after gentle mixing, were 
TABle 2: Phage titers (pfu/mL) for B. subtilis strains.

\begin{tabular}{lcccc}
\hline Phage & SIO $\Phi$ & SUB $\omega$ & SPO $\sigma$ & AR $\pi$ \\
\hline $\begin{array}{l}\text { Bacillus } \\
\text { strain }\end{array}$ & $\begin{array}{c}\text { B. subtilis } \\
10\end{array}$ & $\begin{array}{c}\text { B. subtilis } \\
\text { ATCC 6633 }\end{array}$ & $\begin{array}{c}\text { B. subtilis } \\
\text { SWV215 }\end{array}$ & $\begin{array}{c}\text { B. subtilis } \\
\text { B3 }\end{array}$ \\
\hline $\begin{array}{l}\text { Phage titer } \\
\text { (pfu/mL) }\end{array}$ & $10^{13}$ & $10^{10}$ & $10^{10}$ & $10^{12}$ \\
\hline
\end{tabular}

centrifuged at $3000 \times \mathrm{g}, 4^{\circ} \mathrm{C}$ for $15 \mathrm{~min}$. Partly purified phage particles in the aqueous phase were pelleted by ultracentrifugation (Beckman Coulter) at $50000 \mathrm{rpm}$ at $4^{\circ} \mathrm{C}$ for $60 \mathrm{~min}$. The pellets were resuspended in 1X Laemmli loading buffer $(62.5 \mathrm{mM}$ Tris- $\mathrm{HCl}, 2 \%$ SDS (w/v), 5\% $\beta$ mercaptoethanol (v/v), 10\% glycerol (v/v), 0.04\% (w/v) bromophenol blue; $\mathrm{pH}$ 6.8), boiled for $5 \mathrm{~min}$, and separated on the SDS-PAGE $12 \%$ gel. All gels were run at $40 \mathrm{~mA}$ using a mini Protean apparatus (BioRad) and Laemmli buffer. Gels were stained with Gel Code Blue stain reagent (Thermo Scientific). Biorad Quantity One software was used for the molecular analysis of the phage structural proteins based upon a PageRuler prestained protein ladder plus (Fermentas).

2.10. Statistical Analysis. All experiments were performed at least in triplicate. For the statistical analysis of data obtained, Microsoft Excel 2007 (SD and $t$-test) and R (ANOVA) programs were applied. Standard deviation was included in figures. Statistical significance was determined using Student's $t$-test. The significance level was set at $P<0.05$.

\section{Results}

3.1. Phage Isolation. Bacillus subtilis-specific bacteriophages were isolated from soil inoculated with four distinct (isolated from different locations) B. subtilis strains: 10, B3, ATTC 6633 , and SWV215. All isolated phages formed clear plaques with the strains used for isolation. Phage titers ranged from $10^{10}$ for SUB $\omega$ and SPO $\sigma$ to $10^{13}$ for SIOФ (Table 2).

3.2. Phage Typing. Twenty Bacillus subtilis strains were used to determine the specificity of the four isolated bacteriophages: $\mathrm{SUB} \omega, \mathrm{SPO} \sigma$, SIO $\Phi$, and AR $\pi$ (Table 1). Phage SUB $\omega$ infected all Bacillus strains tested with the exception of $B$. subtilis 10. For B. subtilis 168, B20, KT20, B24, and PCM 486 the resulting plaques were hazy. Phage SPO $\sigma$ did not form plaques with $B$. subtilis 10 and KT20 strains, but formed distinct clear plaques with all other strains. Phage SIOФ formed plaques with $B$. subtilis strains 168,10 , KT20, and PCM 2226 but clear plaques were observed only with Bacillus strains 10 and PCM 2226. Phage AR $\pi$ did not form plaques with strains ATCC 6633, SWV215, 10, PCM1938, PCM 2226, PCM 2189, and PCM 2224. Clear plaques were observed for P22 and 172 strains and for B3 and its mutants (Table 1).

3.3. Phage Morphology. The phages belonged to two morphotypes. Three phages (SIO $\Phi$, SUB $\omega$, and SPO $\sigma$ ) were classified to Myoviridae because of the appearance of icosahedral heads and contractile tails with necks, collars, and base plates
TABle 3: Particle sizes of SIO $\Phi, \operatorname{SUB} \omega, \mathrm{SPO} \sigma$, and $\mathrm{AR} \pi$ phages.

\begin{tabular}{lccc}
\hline Host & Phage & $\begin{array}{c}\text { Head diameter } \\
{[\mathrm{nm} \times \mathrm{nm}]}\end{array}$ & $\begin{array}{c}\text { Tail length } \\
{[\mathrm{nm}]}\end{array}$ \\
\hline $\begin{array}{l}\text { B. subtilis 10 } \\
\begin{array}{l}\text { B. subtilis } \\
\text { ATCC 6633 }\end{array}\end{array}$ SIO $\Phi$ & $100 \times 90$ & 208 \\
\hline $\begin{array}{l}\text { B. subtilis } \\
\text { SWV215 }\end{array}$ & SPO $\sigma$ & $67 \times 67$ & 223 \\
\hline B. subtilis B3 & $\mathrm{AR} \pi$ & $41 \times 47$ & 70 \\
\hline
\end{tabular}

(Figures 1(a), 1(b), and 1(c)). Phage head and tail length also indicated relationship to the Myoviridae (Table 3).

Bacteriophage $\mathrm{AR} \pi$ had icosahedral heads and noncontractile, long tails (Figure 1(d), Table 3 ) and is thus morphologically similar to phages belonging to Siphoviridae family.

3.4. Thermal and $p H$ Stability Test. The thermal stability test was carried out to determine the heat resistance of tested phages at $\mathrm{pH}$ 7.0. All phages were stable after $180 \mathrm{~min}$ at $-80^{\circ} \mathrm{C},-20^{\circ} \mathrm{C}, 4^{\circ} \mathrm{C}, 23^{\circ} \mathrm{C}, 30^{\circ} \mathrm{C}, 37^{\circ} \mathrm{C}$, and $50^{\circ} \mathrm{C}$, and all phages retained $100 \%$ infection activity after a $1 \mathrm{~min}$ incubation at $90^{\circ} \mathrm{C}, 100^{\circ} \mathrm{C}$, and $121^{\circ} \mathrm{C}$ (data not shown). An ANOVA test was done and the interaction between the types of phage tested parameters was found statistically important. Thus, it can be said that the inactivation rate of the phages varies for different types of phages.

Phage SIO $\Phi$ lost total activity after $2 \mathrm{~min}$ at $80^{\circ} \mathrm{C}, 30 \mathrm{~min}$ at $70^{\circ} \mathrm{C}$, and at $60^{\circ} \mathrm{C}$ only $1 \%$ of original activity was observed after a $3 \mathrm{~h}$ incubation period. Phage $\mathrm{SUB} \omega$ lost its infective ability after $1 \mathrm{~min}$ at $80^{\circ} \mathrm{C}, 5 \mathrm{~min}$ at $70^{\circ} \mathrm{C}$, and $180 \mathrm{~min}$ at $60^{\circ} \mathrm{C}$. Phage SPO $\sigma$ was inactive after $2 \mathrm{~min}$ at $80^{\circ} \mathrm{C}, 15 \mathrm{~min}$ at $70^{\circ} \mathrm{C}$, and $60 \mathrm{~min}$ at $60^{\circ} \mathrm{C}$, respectively. Phage $\mathrm{AR} \pi$ lost its activity after $2 \mathrm{~min}$ at $80^{\circ} \mathrm{C}, 10 \mathrm{~min}$ at $70^{\circ} \mathrm{C}$, and 3 hours at $60^{\circ} \mathrm{C}$ (Figures 2(a), 2(b), 2(c), and 2(d)).

Optimal $\mathrm{pH}$ was determined by testing the stability of phages at different $\mathrm{pH}$ after $60 \mathrm{~min}$ (data not shown) and $6 \mathrm{~h}$ of incubation at room temperature $\left(25^{\circ} \mathrm{C}\right)$. After 1-hour incubation at pH 2.0 all tested phages lost infective ability. Statistically significant differences between tested phages were found. Phage SPO $\sigma$ seems to be extremely stable in the $\mathrm{pH}$ range 6.0-8.0; after a $6 \mathrm{~h}$ incubation the $\mathrm{SPO} \sigma$ activity was reduced from $10^{7}$ to $10^{4} \mathrm{pfu} / \mathrm{mL}$ at $\mathrm{pH} 3.0$ and $\mathrm{pH} 4.0$ (Figure 3(c)). At alkaline $\mathrm{pH}$ of 10.0 and $\mathrm{pH} 11.0$ the activity was reduced by one order of magnitude (Figure 3(c)).

Bacteriophage $\mathrm{AR} \pi$ was the most sensitive to acid and alkaline conditions and only showed $100 \%$ activity at $\mathrm{pH} 7.0$ and pH 8.0 (Figure 3(d)). Similar results were observed after only 1 hour incubation (data not shown).

Phages SIOФ and SUB $\omega$ had $100 \%$ activity in the $\mathrm{pH}$ range of 6.0-8.0 and SIOФ had reduced activity at $\mathrm{pH} 4.0$, 5.0 , and 9.0 from $10^{7}$ to $10^{2}, 10^{3}$, and $10^{3}$, respectively (Figures 3(a) and 3(b)).

Phage SIOФ was the most active in the adsorption (50\%) to the B. subtilis 10 strain. The one-step growth curve of SIO $\Phi$ indicated that the latent period was 55-65 min and the estimated burst size was $\sim 74$ phage particles per infected 


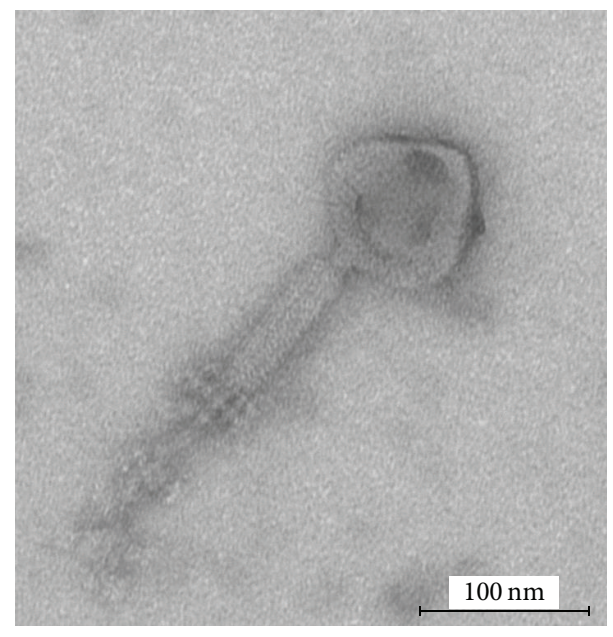

(a) $\operatorname{SIO\Phi }$

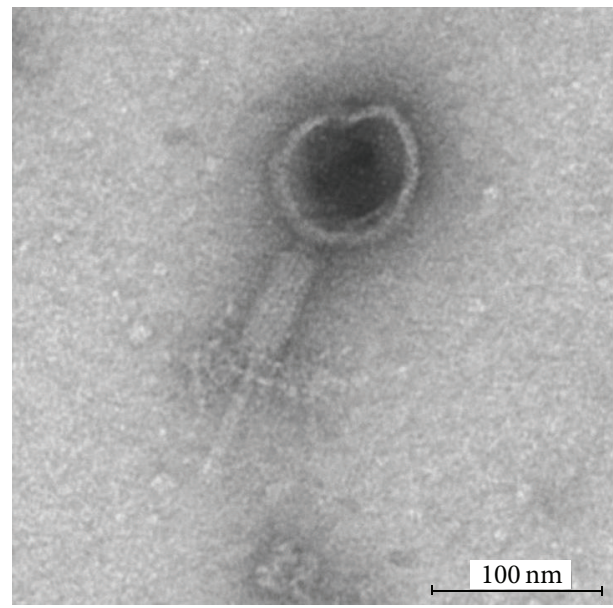

(c) $\mathrm{SPO} \sigma$

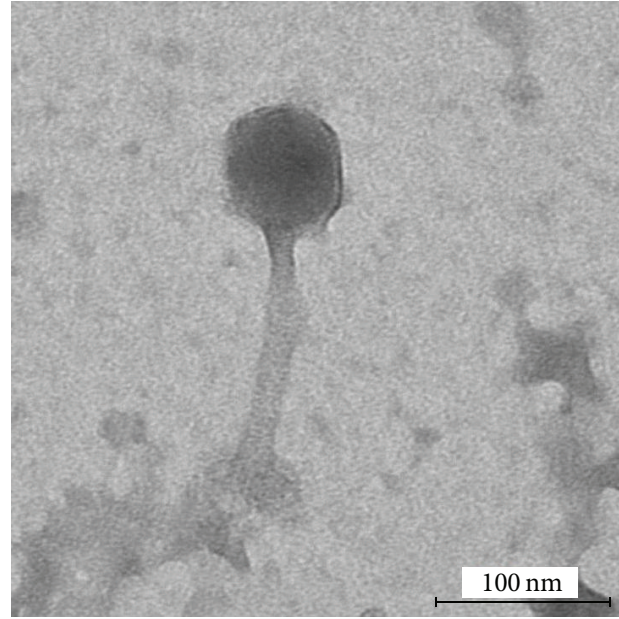

(b) $\mathrm{SUB} w$

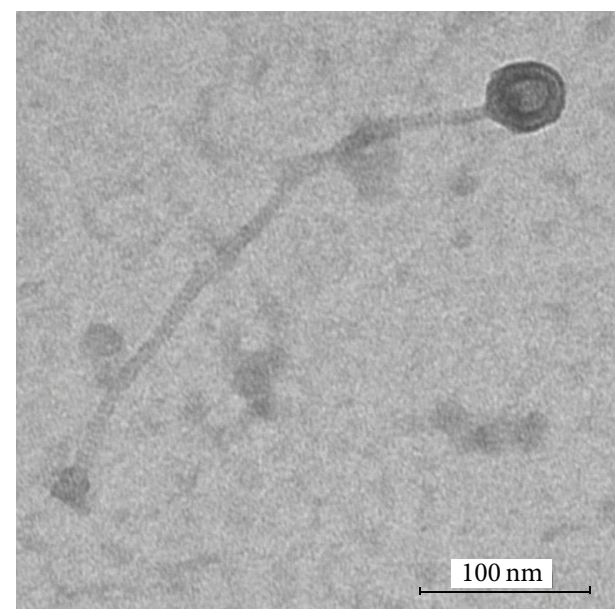

(d) $\mathrm{AR} \pi$

FIgURE 1: Transmission electron microscopic images of (a) B. subtilis 10 phage SIOФ, (b) B. subtilis ATCC 6633 phage SUB $\omega$, (c) B. subtilis SWV215 phage $\mathrm{SPO} \sigma$, and B. subtilis B3 phage AR $\pi$.

TABLE 4: Biological characteristics of SIO $\Phi, \operatorname{SUB} \omega, \mathrm{SPO} \sigma$, and $\mathrm{AR} \pi$ phages.

\begin{tabular}{lcccc}
\hline Phage & $\begin{array}{c}\text { Adsorption } \\
{[\%]}\end{array}$ & $\begin{array}{c}\text { Burst size } \\
{[\mathrm{pfu} / \mathrm{mL}]}\end{array}$ & $\begin{array}{c}\text { Latent period } \\
{[\mathrm{min}]}\end{array}$ & $\begin{array}{c}\text { Growth time } \\
{[\mathrm{min}]}\end{array}$ \\
\hline $\mathrm{SIO} \Phi$ & 50 & $\sim 74$ & $55-65$ & 40 \\
$\mathrm{SUB} \omega$ & 12 & $\sim 8$ & $55-65$ & 30 \\
$\mathrm{SPO} \sigma$ & 7.5 & $\sim 23$ & $75-85$ & 40 \\
$\mathrm{AR} \pi$ & 12 & $\sim 37$ & $55-65$ & 30 \\
\hline
\end{tabular}

bacterial cell (Table 4). Phage SPO $\sigma$ was less active. It was adsorbed by only $7.5 \%$ of the B. subtilis SWV 215 strain. The latent period of $\mathrm{SPO} \sigma$ was $75-85 \mathrm{~min}$ and the estimated burst size was $\sim 23$ phage particles per infected bacterial cell (Table 4). The latent periods of phages SUB $\omega$ and $A R \pi$ were the same as that of phage SIO $\Phi$, but the adsorption was lower (12\%) and growth times were shorter (30 min). A difference between phages $\mathrm{SUB} \omega$ and $\mathrm{AR} \pi$ was observed in their burst size: for $\mathrm{SUB} \omega$ it was only $\sim 8$ phage particles per infected bacterial cell while for $\mathrm{AR} \pi$ it was $\sim 37$ phage particles (Table 4).

3.5. Phage Genome Size Estimated by PFGE. The size of the intact genomic DNA of the four phages in this study was estimated by pulse-field electrophoresis (PFGE). For phages SIO $\Phi$, SUB $\omega$, and SPO $\sigma$ belonging to Myoviridae family the size of their genomes was, respectively, 154, 154, and $25 \mathrm{kbp}$ (Figure 4). The genome size of $\operatorname{Ar} \pi$, the only phage from Siphoviridae family, was $40 \mathrm{kbp}$ (Figure 4). The determined genome size values are comparable with values estimated by ICTV for the indicated phage families.

3.6. Protein Composition. SDS-PAGE was used to determine the content of structural proteins of phage particles. Virions of phages $\mathrm{SIO} \Phi, \mathrm{SUB} \omega$, and $\mathrm{SPO} \sigma$ contained structural proteins with predominant protein bands corresponding, respectively, to $\sim 52 \mathrm{kDa}(\mathrm{SIO} \Phi), \sim 45,31 \mathrm{kDa}(\mathrm{SUB} \omega)$, and $45 \mathrm{kDa}(\mathrm{SPO} \sigma)$ (Figure 5). Phage $\mathrm{AR} \pi$ contained at least 14 structural proteins and was found to produce three major 


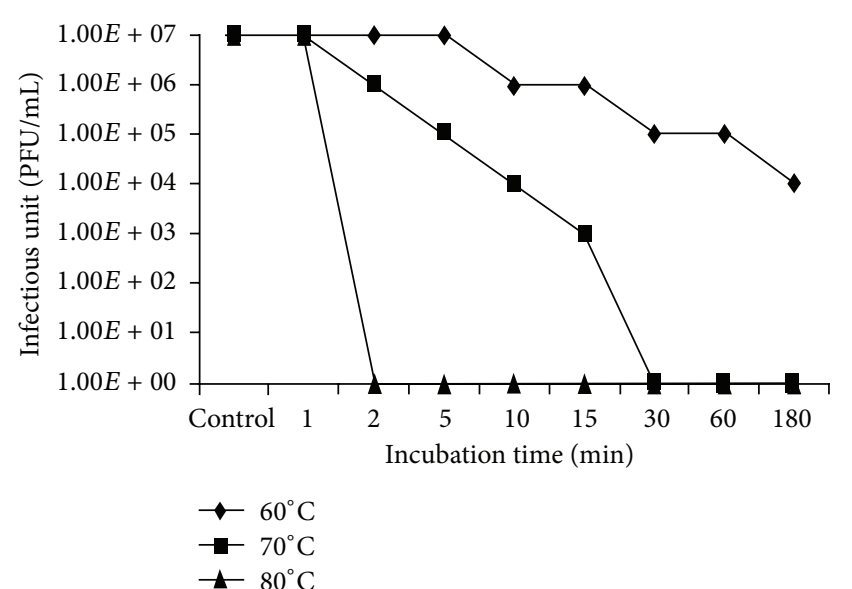

(a)

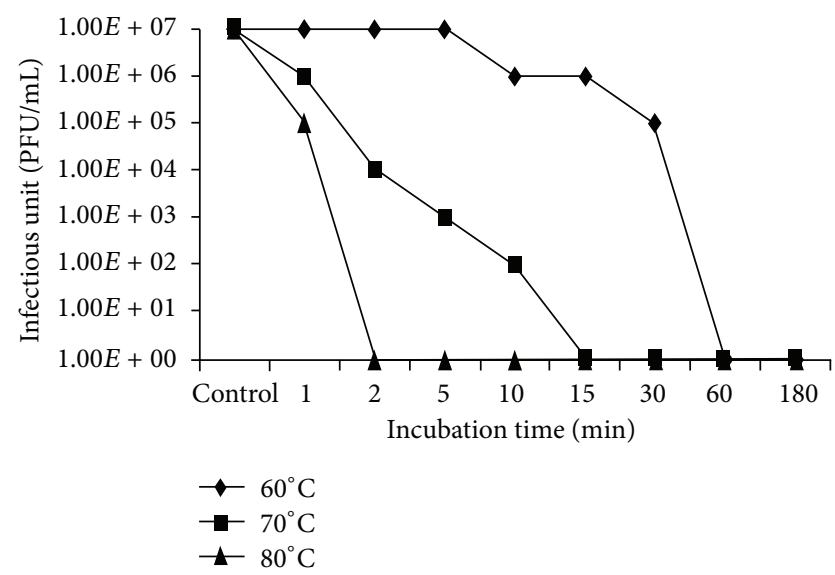

(c)

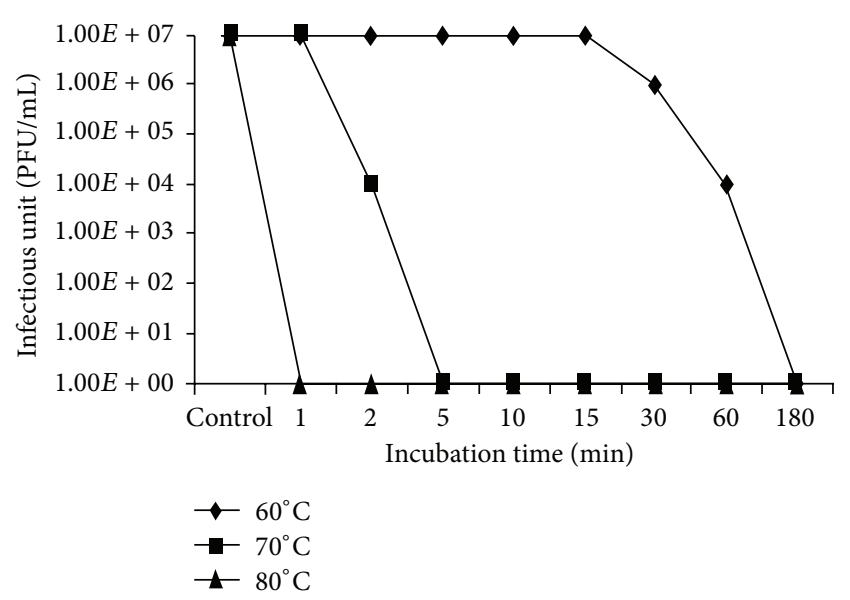

(b)

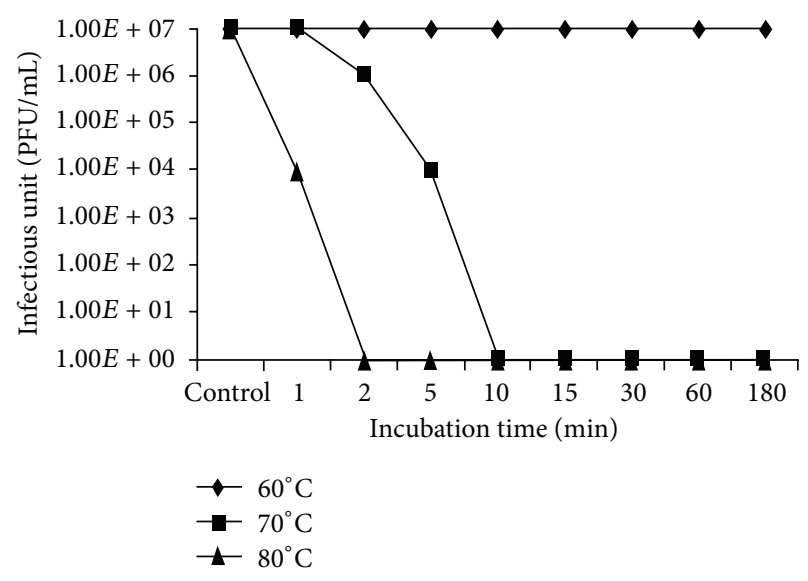

(d)

FIgUre 2: Thermal stability test of phages: (a) SIO $\Phi$, (b) SUB $\omega$, (c) SPO $\sigma$, and (d) AR $\pi$.

protein bands at molecular masses of approximately 42, 37, and $31 \mathrm{kDa}$ (Figure 5).

\section{Discussion}

Bacillus has a high prevalence in nature and ability to form heat-resistant endospores; hence it is difficult to eradicate it from, for example, fermented food, and the constant presence of beneficial microorganisms is critical to maintaining the expected food quality. Bacteriophages are host-specific natural enemies of bacteria and the efficient eradication of bacterial pathogens with the use of phages is an effective way to control harmful bacteria $[2,49]$.

Bacteriophages may have distinct applications, such as biocontrol (eradication) of unwanted species (strains), improvement (selection) of strains used for production, and strain typing. All these applications depend on phage specificity [50]. Both a wide and a narrow host range may be useful. While a rather narrow host range will enable distinction of closely related strains in strain typing, a rather wide host range will be beneficial for biocontrol. In comparison to biocontrol, application of bacteriophages for improvement and selection of industrial strains has been poorly described.
In fact, it is well known that in a large-scale production phage infection may lead to the collapse of the production, as it was in the case of acetone-butanol fermentation [51]. Thus, in industrial practice either various strains are used every month or a cocktail of strains is used for inoculum. Rotation of strains with various resistance decreases the risk of accumulation of bacteriophages infecting producer strain in industrial environment [52].

We found four bacteriophages with different specificity toward twenty Bacillus subtilis strains (Table 1). The classification of bacteriophages is in most cases based on morphological criteria and rarely on molecular data, for example, nucleotide sequence homology [53]. Considering the morphology, $96 \%$ of all bacteriophages belong to the order Caudovirales and this order is subdivided into three families: the Myoviridae (25\%), characterized by a contractile tail; the Siphoviridae (61\%) with a noncontractile tail; and the Podoviridae (14\%) with a short, noncontractile tail [54, 55]. In 2009 the International Committee on the Taxonomy of Viruses (ICTV) proposed the creation the Myoviridae subfamily Spounavirinae with genera of SPO1-like viruses and Twort-like viruses and eight phage species [56]. Recently, Klumpp et al. [57] proposed a revision of current taxonomic 


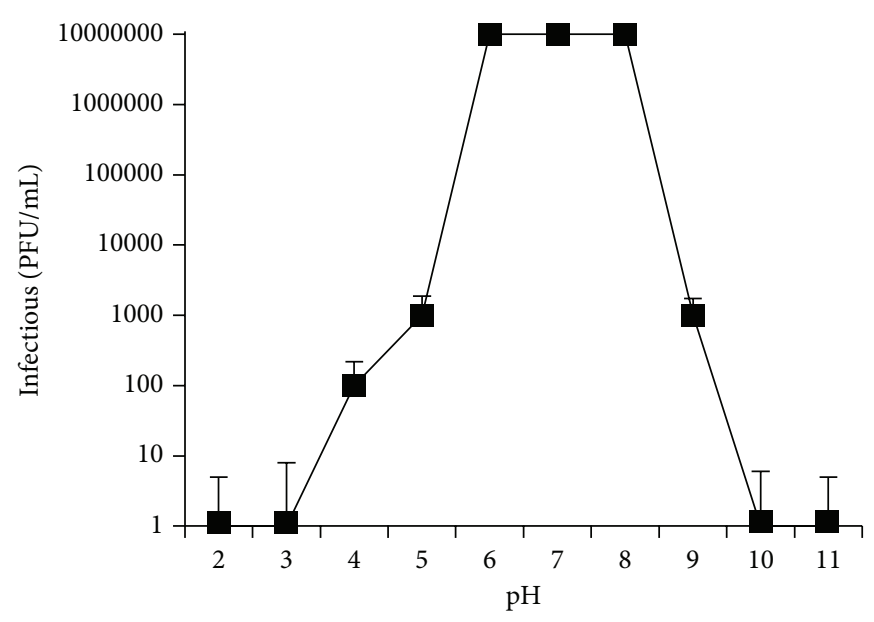

(a)

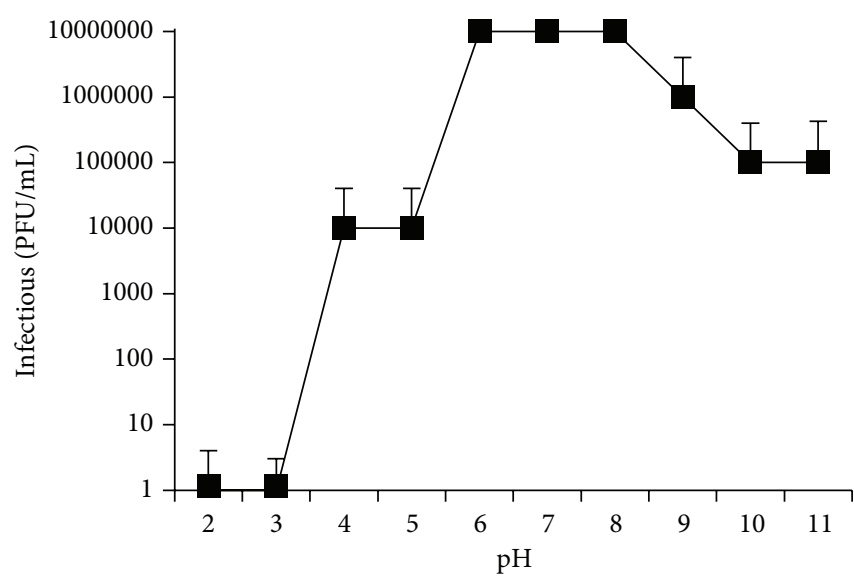

(c)

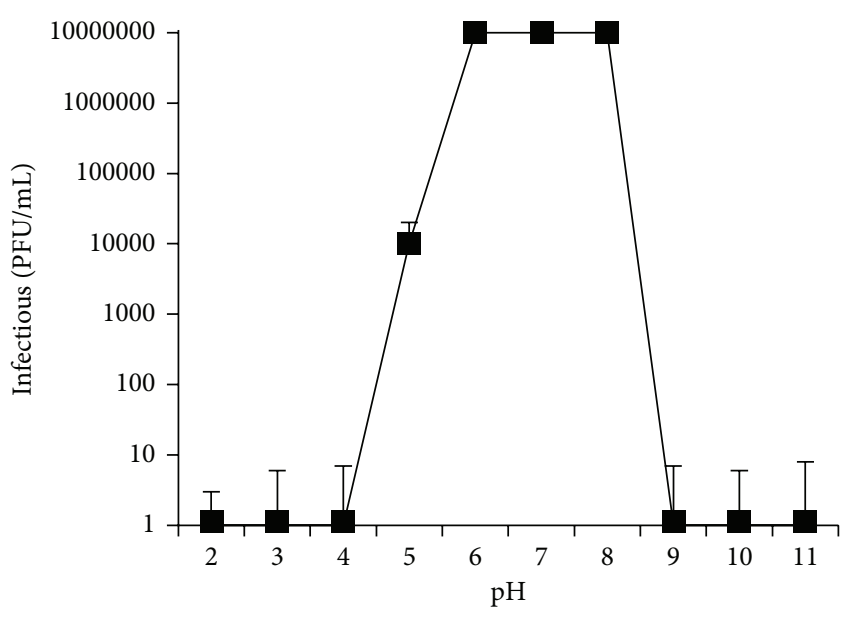

(b)

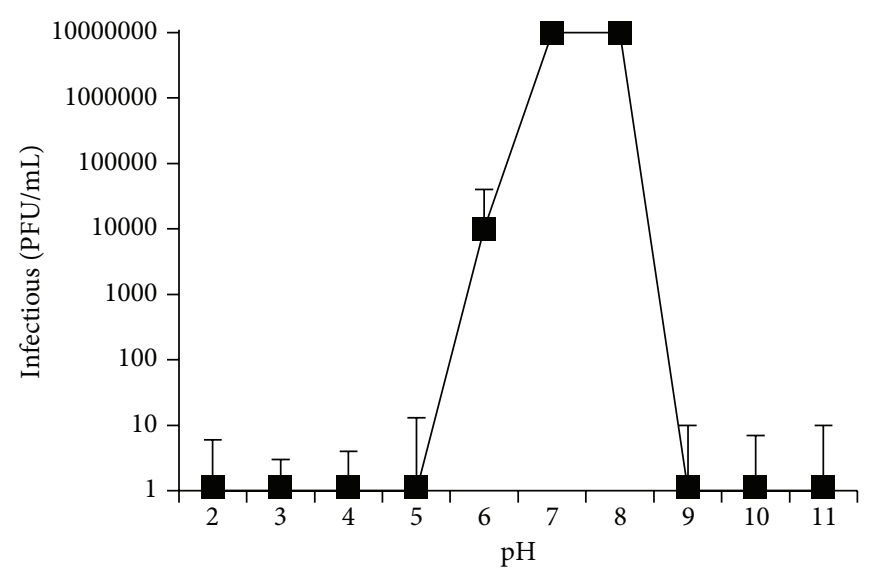

(d)

Figure 3: pH stability test of phages: (a) SIOФ, (b) SUB $\omega$, (c) SPO $\sigma$, and (d) AR $\pi$. Data are the means from three independent experiments $+\mathrm{SD}$.

organization of the family Myoviridae and evaluated new members of this group. In this work we isolated three phages, $\mathrm{SIO} \Phi, \mathrm{SUB} \omega$, and $\mathrm{SPO} \sigma$, which morphologically belong to the Myoviridae family and phage AR $\pi$ which is classified in the Siphoviridae family (Figure 1). The genomes of SIOФ and SUB $\omega$ are $154 \mathrm{kbp}$ each and are similar to the other phages of Bacillus subtilis such as SPO1 (145.7 kbp), SP8, SP82G, H1, 2C, Фe, or $Ф 25$ ( 150) [57]. SIOФ has only four capsid proteins like the $\Phi H$-like viruses; however, viruses of the $\Phi H$ type have a mere $59 \mathrm{kbp}$ genome [58]. Bacteriophage SPO $\sigma$ has a genome size of $25 \mathrm{kbp}$ and $\sim 14$ capsid proteins and these features allow it to fall into the group of P2-like or $\mathrm{Mu}$-like viruses but, unfortunately, viruses in this class have Gram-negative bacteria as hosts [58]. AR $\pi$ phage genome is sized $40 \mathrm{kbp}$ and it has $\sim 14$ capsid proteins. On the basis of these characteristics it can be classified as $\mathrm{N}_{15}$-like virus but the very long tail $(342 \mathrm{~nm})$ excludes it from the known classification [58]. The bacteriophages with the longest tails in Siphoviridae family belong to $\Phi M_{1}$-like viruses $(210 \mathrm{~nm})$ and their tail is terminated with a knob as in $\mathrm{AR} \pi$ phage.

The use of bacteriophages in biotechnological processes requires the knowledge of their characteristics such as the host range, latent period, growth time, or the resistance to stress conditions, for example, different temperatures or $\mathrm{pH}$. Temperature plays a crucial role in bacteriophage survival, capacity for attachment, and the length of the latent period [59]. $\mathrm{SIO} \Phi, \mathrm{SUB} \omega, \mathrm{SPO} \sigma$, and $\mathrm{AR} \pi$ bacteriophages retain a stable activity following 3 hours at temperatures ranging from $-80^{\circ} \mathrm{C}$ to $50^{\circ} \mathrm{C}$ (Figure 2). Phages $\operatorname{SIO} \Phi, \operatorname{SPO} \sigma$, and $\mathrm{AR} \pi$ proved to be resistant to high temperatures and all of them survive after $2 \mathrm{~min}$ at $80^{\circ} \mathrm{C}, 5 \mathrm{~min}$ or longer at $70^{\circ} \mathrm{C}$, and $180 \mathrm{~min}$ (except for $60 \mathrm{~min}$ for $\mathrm{SPO} \sigma$ ) at $60^{\circ} \mathrm{C}$ (Figure 2). In general, members of Myoviridae and Siphoviridae families are considered to be resistant to large temperature fluctuations [35].

Acidity and alkalinity of the environment are other important factors influencing phage stability. SIO $\Phi$ and SPO $\sigma$ phages are the most resistant to acid (4.0) and alkaline (9.0 and 10.0) $\mathrm{pH} ; \mathrm{AR} \pi$ phage is the least resistant to $\mathrm{pH}$ fluctuations. The optimum $\mathrm{pH}$ values for all investigated phages were 7.0 and 8.0 (Figure 3). Lasobras et al. [60] have suggested that members of Siphoviridae family are the most resistant to adverse conditions. However, phage $\operatorname{Ar} \pi$, which we morphologically classified as a member of Siphoviridae, is only active in a narrow $\mathrm{pH}$ range (6.0-8.0). 

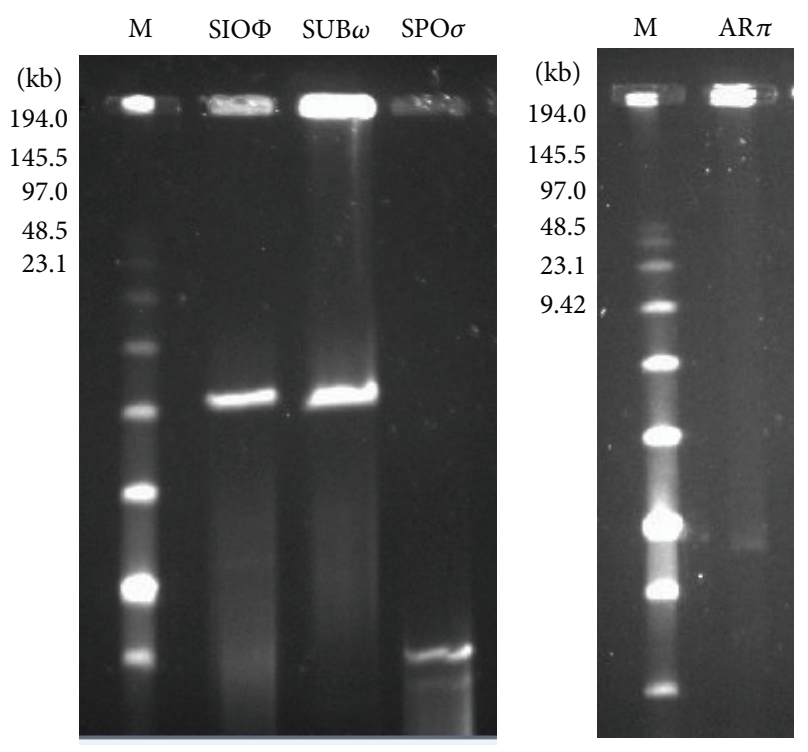

FIgUre 4: Pulsed-field gel electrophoresis of undigested phage DNAs. Genome sizes were estimated by using Low Range PFG marker $(\mathrm{M})$.

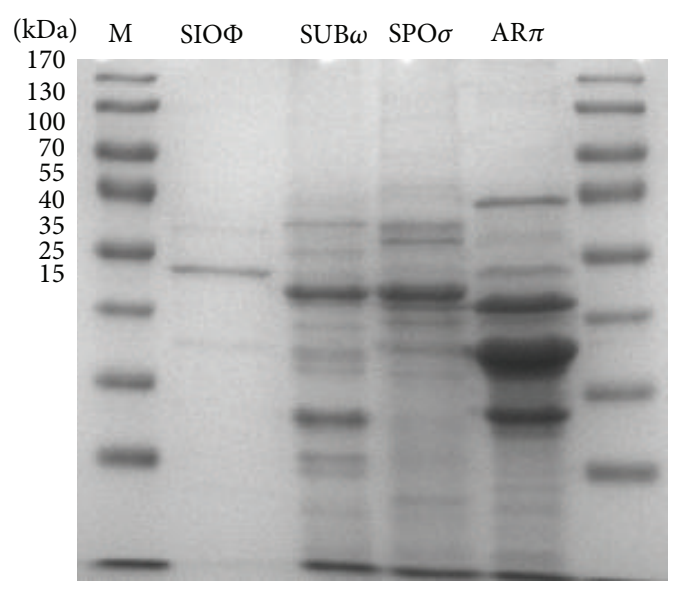

FIGURE 5: SDS-polyacrylamide gel electrophoretic analysis of indicated virion proteins estimated by using PageRuler prestained protein ladder plus $(\mathrm{M})$.

Bacteriophage SIO $\Phi$ had the highest percent adsorption to the Bacillus host (50\%) and released the largest number of particles ( 74) from host cells (Table 4 ) and its phage titer was the highest $\left(10^{13}\right.$ ) (Table 2). Due to high activity at low and high temperature and $\mathrm{pH}, \operatorname{SIO} \Phi$ seems to be the best candidate for use in industry.

The literature contains many descriptions of experiments conducted under different conditions and hence with varying results. Some Bacillus subtilis phages such as SP02c1 or SP82 have a higher percent of adsorption than our phages [61] while, on the other hand, phage SPO1 has the same burst size as $\operatorname{SIO\Phi ~[62].~}$

At least one of the characterized isolated bacteriophages was lytic for each tested strain of Bacillus subtilis. Thus, they could be suitable for the phagotyping of this bacterial species.

\section{Conflict of Interests}

The authors declare that there is no conflict of interests regarding the publication of this paper.

\section{Acknowledgments}

This work was supported by grants from the Polish National Centre for Research and Development KB/48/13639/IT1B/U/08, Grant EU POIG.01.01.02-00-016/2008, grant of the Ministry of Science and Higher Education (Poland) and the European Union within European Regional Development Fund, through Innovative Economy Grant (POIG.01.01.0200-008/08), and by Wroclaw Centre of Biotechnology, programme The Leading National Research Centre (KNOW) for years 2014-2018.

\section{References}

[1] S. Hagens and M. J. Loessner, "Application of bacteriophages for detection and control of foodborne pathogens," Applied Microbiology and Biotechnology, vol. 76, no. 3, pp. 513-519, 2007.

[2] S. Guenther, D. Huwyler, S. Richard, and M. J. Loessner, "Virulent bacteriophage for efficient biocontrol of listeria monocytogenes in ready-to-eat foods," Applied and Environmental Microbiology, vol. 75, no. 1, pp. 93-100, 2009.

[3] L. Y. Brovko, H. Anany, and M. W. Griffiths, "Bacteriophages for detection and control of bacterial pathogens in food and foodprocessing environment," in Advances in Food and Nutrition Research, H. Jeyakumar, Ed., chapter 6, pp. 241-288, Academic Press, New York, NY, USA, 2012.

[4] J.-H. Lee, H. Shin, B. Son, S. Heu, and S. Ryu, "Characterization and complete genome sequence of a virulent bacteriophage B4 infecting food-borne pathogenic Bacillus cereus," Archives of Virology, vol. 158, no. 10, pp. 2101-2108, 2013.

[5] N. Bandara, J. Jo, S. Ryu, and K.-P. Kim, "Bacteriophages BCP11 and BCP8-2 require divalent cations for efficient control of Bacillus cereus in fermented foods," Food Microbiology, vol. 31, no. 1, pp. 9-16, 2012.

[6] H. Shin, N. Bandara, E. Shin, S. Ryu, and K.-P. Kim, "Prevalence of Bacillus cereus bacteriophages in fermented foods and characterization of phage JBP901," Research in Microbiology, vol. 162, no. 8, pp. 791-797, 2011.

[7] T. Nagai and F. Yamasaki, "Bacillus subtilis (natto) bacteriophages isolated in Japan," Food Science and Technology Research, vol. 15, no. 3, pp. 293-298, 2009.

[8] W. E. Farrar Jr., "Serious infections due to "non-pathogenic" organisms of the genus bacillus. Review of their status as pathogens," The American Journal of Medicine, vol. 34, no. 1, pp. 134-141, 1963.

[9] J. McFarland, "Bacillus anthracis similis," Zentralbl Bakteriol Parasitenkd Abt I, vol. 24, pp. 556-557, 1898.

[10] A. Akesson, S. A. Hedstrom, and T. Ripa, "Bacillus cereus: a significant pathogen in postoperative and post-traumatic wounds on orthopaedic wards," Scandinavian Journal of Infectious Diseases, vol. 23, no. 1, pp. 71-77, 1991.

[11] D. Barrie, J. A. Wilson, P. N. Hoffman, and J. M. Kramer, "Bacillus cereus meningitis in two neurosurgical patients: an investigation into the source of the organism," Journal of Infection, vol. 25, no. 3, pp. 291-297, 1992. 
[12] D. J. Cotton, V. J. Gill, D. J. Marshall, J. Gress, M. Thaler, and P. A. Pizzo, "Clinical features and therapeutic interventions in 17 cases of Bacillus bacteremia in an immunosuppressed patient population," Journal of Clinical Microbiology, vol. 25, no. 4, pp. 672-674, 1987.

[13] C. S. Block, M. L. Levy, and V. U. Fritz, "Bacillus cereus endocarditis-a case report," South African Medical Journal, vol. 53, no. 4, pp. 556-557, 1978.

[14] J. E. Carbone and J. L. Stauffer, "Bacillus cereus pleuropulmonary infection in a normal host," The Western Journal of Medicine, vol. 143, no. 5, pp. 676-677, 1985.

[15] C. P. Craig, W.-S. Lee, and M. Ho, "Bacillus cereus endocarditis in an addict," Annals of Internal Medicine, vol. 80, no. 3, pp. 418419, 1974.

[16] F. A. Drobniewski, "Bacillus cereus and related species," Clinical Microbiology Reviews, vol. 6, no. 4, pp. 324-338, 1993.

[17] C. From, R. Pukall, P. Schumann, V. Hormazábal, and P. E. Granum, "Toxin-producing ability among Bacillus spp. outside the Bacillus cereus group," Applied and Environmental Microbiology, vol. 71, no. 3, pp. 1178-1183, 2005.

[18] P. B. Pedersen, M. E. Bjørnvad, M. D. Rasmussen, and J. N. Petersen, "Cytotoxic potential of industrial strains of Bacillus sp," Regulatory Toxicology and Pharmacology, vol. 36, no. 2, pp. 155-161, 2002.

[19] M. S. Salkinoja-Salonen, R. Vuorio, M. A. Andersson et al., "Toxigenic strains of Bacillus licheniformis related to food poisoning," Applied and Environmental Microbiology, vol. 65, no. 10, pp. 4637-4645, 1999.

[20] M. C. Te Giffel, R. R. Beumer, S. Leijendekkers, and F. M. Rombouts, "Incidence of Bacillus cereus and Bacillus subtilis in foods in the Netherlands," Food Microbiology, vol. 13, no. 1, pp. 53-58, 1996.

[21] C. P. Bailey and A. von Holy, "Bacillus spore contamination associated with commercial bread manufacture," Food Microbiology, vol. 10, no. 4, pp. 287-294, 1993.

[22] I. B. Sorokulova, O. N. Reva, V. V. Smirnov, I. V. Pinchuk, S. V. Lapa, and M. C. Urdaci, "Genetic diversity and involvement in bread spoilage of Bacillus strains isolated from flour and ropy bread," Letters in Applied Microbiology, vol. 37, no. 2, pp. 169173, 2003.

[23] E. de Clerck, T. Vanhoutte, T. Hebb, J. Geerinck, J. Devos, and P. de Vos, "Isolation, characterization, and identification of bacterial contaminants in semifinal gelatin extracts," Applied and Environmental Microbiology, vol. 70, no. 6, pp. 3664-3672, 2004.

[24] R. Moeller, G. Horneck, R. Facius, and E. Stackebrandt, "Role of pigmentation in protecting Bacillus sp. endospores against environmental UV radiation," FEMS Microbiology Ecology, vol. 51, no. 2, pp. 231-236, 2005.

[25] C. Faille, F. Fontaine, and T. Bénézech, "Potential occurrence of adhering living Bacillus spores in milk product processing lines," Journal of Applied Microbiology, vol. 90, no. 6, pp. 892900, 2001.

[26] E. J. Vandamme, "Phage therapy and phage control: to be revisited urgently!!", Journal of Chemical Technology and Biotechnology, vol. 89, no. 3, pp. 329-333, 2014.

[27] R. W. Hendrix, "Bacteriophages: evolution of the majority," Theoretical Population Biology, vol. 61, no. 4, pp. 471-480, 2002.

[28] G. W. Hanlon, "Bacteriophages: an appraisal of their role in the treatment of bacterial infections," International Journal of Antimicrobial Agents, vol. 30, no. 2, pp. 118-128, 2007.
[29] A. Sulakvelidze, Z. Alavidze, and J. G. Morris Jr., "Bacteriophage therapy," Antimicrobial Agents and Chemotherapy, vol. 45, no. 3, pp. 649-659, 2001.

[30] R. Zink and M. J. Loessner, "Classification of virulent and temperate bacteriophages of Listeria spp. on the basis of morphology and protein analysis," Applied and Environmental Microbiology, vol. 58, no. 1, pp. 296-302, 1992.

[31] C. E. D. Rees, C. E. R. Dodd, S. S. Allen, and I. Laskin, "Phage for rapid detection and control of bacterial pathogens in food," in Advances in Applied Microbiology, pp. 159-186, Academic Press, New York, NY, USA, 2006.

[32] M. Skurnik, M. Pajunen, and S. Kiljunen, "Biotechnological challenges of phage therapy," Biotechnology Letters, vol. 29, no. 7, pp. 995-1003, 2007.

[33] N. K. Petty, T. J. Evans, P. C. Fineran, and G. P. C. Salmond, "Biotechnological exploitation of bacteriophage research," Trends in Biotechnology, vol. 25, no. 1, pp. 7-15, 2007.

[34] H. W. Ackermann, D. Tremblay, and S. Moineau, "Long-term bacteriophage preservation," WFCC Newsletter, vol. 38, pp. 3540, 2004

[35] E. Jończyk, M. Kłak, R. Miedzybrodzki, and A. Górski, “The influence of external factors on bacteriophages-review," Folia Microbiologica, vol. 56, no. 3, pp. 191-200, 2011.

[36] H.-W. Ackermann, R. R. Azizbekyan, R. L. Bernier et al., "Phage typing of Bacillus subtilis and B. thuringiensis," Research in Microbiology, vol. 146, no. 8, pp. 643-657, 1995.

[37] Y. Inatsu, K. Kimura, and Y. Itoh, "Characterization of Bacillus subtilis strains isolated from fermented soybean foods in Southeast Asia: comparison with B. subtilis (natto) starter strains," Japan Agricultural Research Quarterly, vol. 36, no. 3, pp. 169$175,2002$.

[38] K. Kimura and Y. Itoh, "Characterization of poly- $\gamma$-glutamate hydrolase encoded by a bacteriophage genome: possible role in phage infection of bacillus subtilis encapsulated with poly- $\gamma$ glutamate," Applied and Environmental Microbiology, vol. 69, no. 5, pp. 2491-2497, 2003.

[39] K. Xu and M. A. Strauch, "Identification, sequence, and expression of the gene encoding $\gamma$-glutamyltranspeptidase in Bacillus subtilis," Journal of Bacteriology, vol. 178, no. 14, pp. 4319-4322, 1996.

[40] S. Yao, X. Gao, N. Fuchsbauer, W. Hillen, J. Vater, and J. Wang, "Cloning, sequencing, and characterization of the genetic region relevant to biosynthesis of the lipopeptides iturin A and surfactin in Bacillus subtilis," Current Microbiology, vol. 47, no. 4, pp. 0272-0277, 2003.

[41] L. K. Nakamura, "Taxonomic relationship of black-pigmented Bacillus subtilis strains and a proposal for Bacillus atrophaeus sp. nov," International Journal of Systematic Bacteriology, vol. 39, no. 3, pp. 295-300, 1989.

[42] M. Adams, Bacteriophages, Interscience, New York, NY, USA, 1959.

[43] H. Yang, L. Liang, S. Lin, and S. Jia, "Isolation and characterization of a virulent bacteriophage $\mathrm{AB} 1$ of Acinetobacter baumannii," BMC Microbiology, vol. 10, no. 1, p. 131, 2010.

[44] R. Gallet, Y. Shao, and I.-N. Wang, "High adsorption rate is detrimental to bacteriophage fitness in a biofilm-like environment," BMC Evolutionary Biology, vol. 9, no. 1, article 241, 2009.

[45] C. Roncero, A. Darzins, and M. J. Casadaban, "Pseudomonas aeruginosa transposable bacteriophages D3112 and B3 require pili and surface growth for adsorption," Journal of Bacteriology, vol. 172, no. 4, pp. 1899-1904, 1990. 
[46] M. Pajunen, S. Kiljunen, and M. Skurnik, "Bacteriophage $\varphi$ YeO3-12, specific for Yersinia enterocolitica serotype O:3, is related to coliphages T3 and T7," Journal of Bacteriology, vol. 182, no. 18, pp. 5114-5120, 2000.

[47] J. Sambrook and D. W. Russell, Molecular Cloning, Cold Spring Harbor Laboratory, New York, NY, USA, 2001.

[48] E. Lingohr, S. Frost, and R. P. Johnson, "Determination of bacteriophage genome size by pulsed-field gel electrophoresis," Methods in Molecular Biology, vol. 502, pp. 19-25, 2009.

[49] P. García, B. Martínez, J. M. Obeso, and A. Rodríguez, "Bacteriophages and their application in food safety," Letters in Applied Microbiology, vol. 47, no. 6, pp. 479-485, 2008.

[50] S. Hagens and M. J. Loessner, "Bacteriophage for biocontrol of foodborne pathogens: calculations and considerations," Current Pharmaceutical Biotechnology, vol. 11, no. 1, pp. 58-68, 2010.

[51] W. Kuit, N. P. Minton, A. M. López-Contreras, and G. Eggink, "Disruption of the acetate kinase (ack) gene of Clostridium acetobutylicum results in delayed acetate production," Applied Microbiology and Biotechnology, vol. 94, no. 3, pp. 729-741, 2012.

[52] A. Gálvez, H. Abriouel, R. L. López, and N. B. Omar, "Bacteriocin-based strategies for food biopreservation," International Journal of Food Microbiology, vol. 120, no. 1-2, pp. 51-70, 2007.

[53] H.-W. Ackermann, "Phage classification and characterization," Methods in Molecular Biology, vol. 501, pp. 127-140, 2009.

[54] H. W. Ackermann, "Bacteriophage observations and evolution," Research in Microbiology, vol. 154, no. 4, pp. 245-251, 2003.

[55] H.-W. Ackermann, "5500 Phages examined in the electron microscope," Archives of Virology, vol. 152, no. 2, pp. 227-243, 2007.

[56] R. Lavigne, P. Darius, E. J. Summer et al., "Classification of myoviridae bacteriophages using protein sequence similarity," BMC Microbiology, vol. 9, article 224, 2009.

[57] J. Klumpp, R. Lavigne, M. J. Loessner, and H.-W. Ackermann, "The SPO1-related bacteriophages," Archives of Virology, vol. 155, no. 10, pp. 1547-1561, 2010.

[58] C. M. Fauquet, M. A. Mayo, J. Maniloff, U. Desselberger, and A. Ball, VIII Report of the International Committe on the Taxonomy of Viruses-Virus Taxonomy Classification and Nomenclature, Elsevier/Academic Press, London, UK, 2005.

[59] M. R. Olson, R. P. Axler, and R. E. Hicks, "Effects of freezing and storage temperature on MS2 viability," Journal of Virological Methods, vol. 122, no. 2, pp. 147-152, 2004.

[60] J. Lasobras, M. Muniesa, J. Frías, F. Lucena, and J. Jofre, "Relationship between the morphology of bacteriophages and their persistence in the environment," Water Science and Technology, vol. 35, no. 11-12, pp. 129-132, 1997.

[61] S. Palefski, H. E. Hemphill, P. E. Kolenbrander, and H. R. Whiteley, "Dominance relationships in mixedly infected Bacillus subtilis," Journal of Virology, vol. 9, no. 4, pp. 594-601, 1972.

[62] A. Sampath and C. R. Stewart, "Roles of genes 44, 50, and 51 in regulating gene expression and host takeover during infection of Bacillus subtilis by bacteriophage SPO1," Journal of Bacteriology, vol. 186, no. 6, pp. 1785-1792, 2004. 

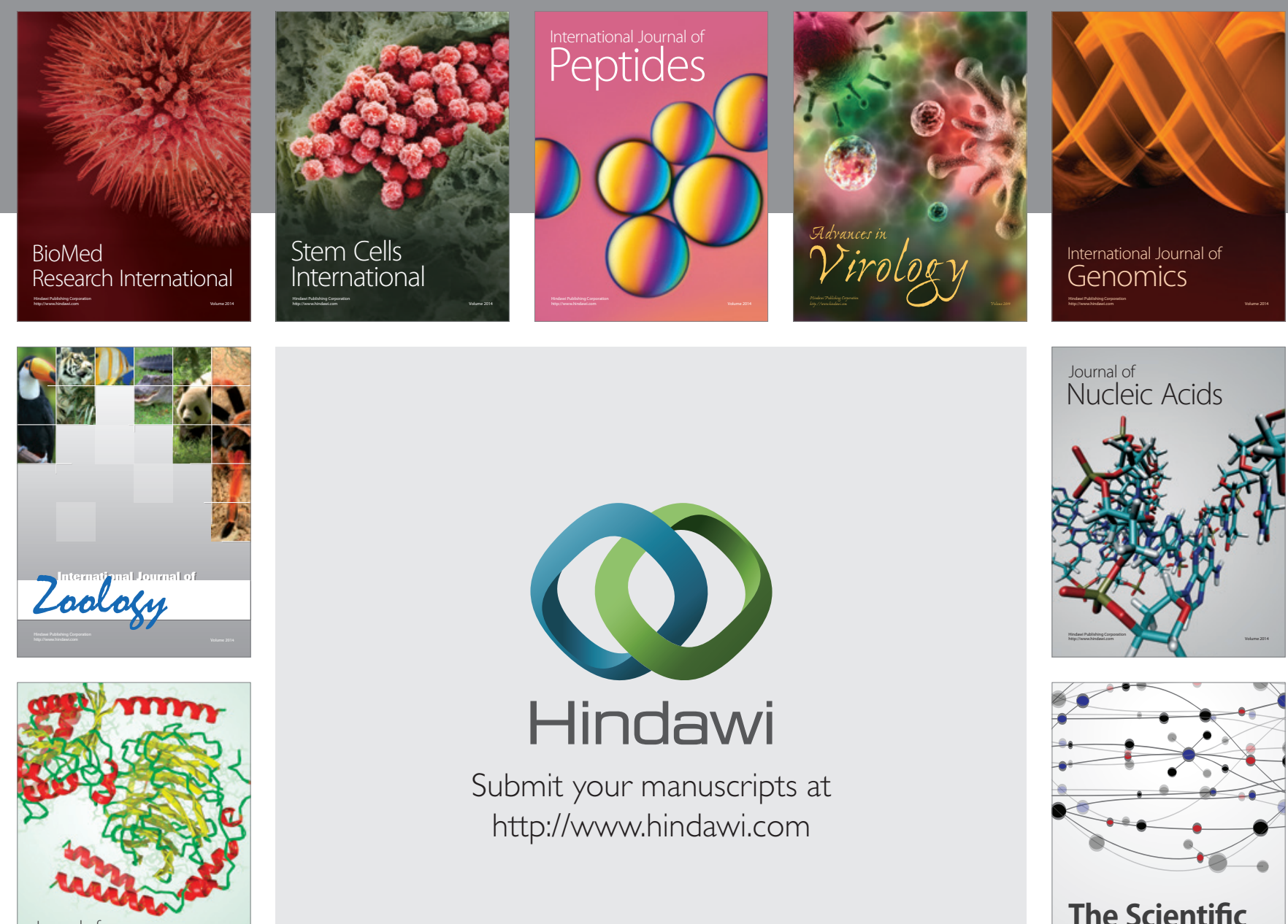

Submit your manuscripts at

http://www.hindawi.com

Journal of
Signal Transduction
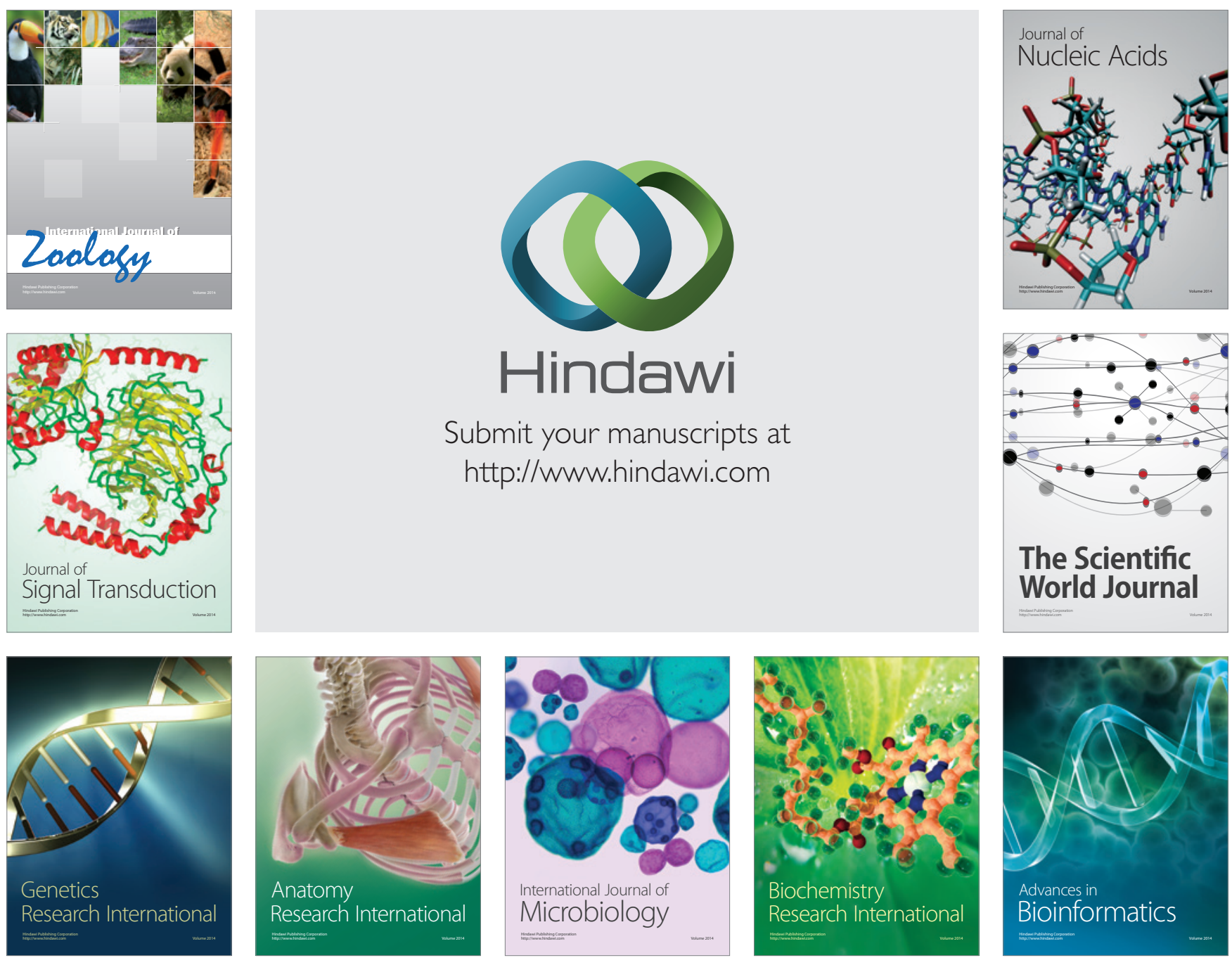

The Scientific World Journal
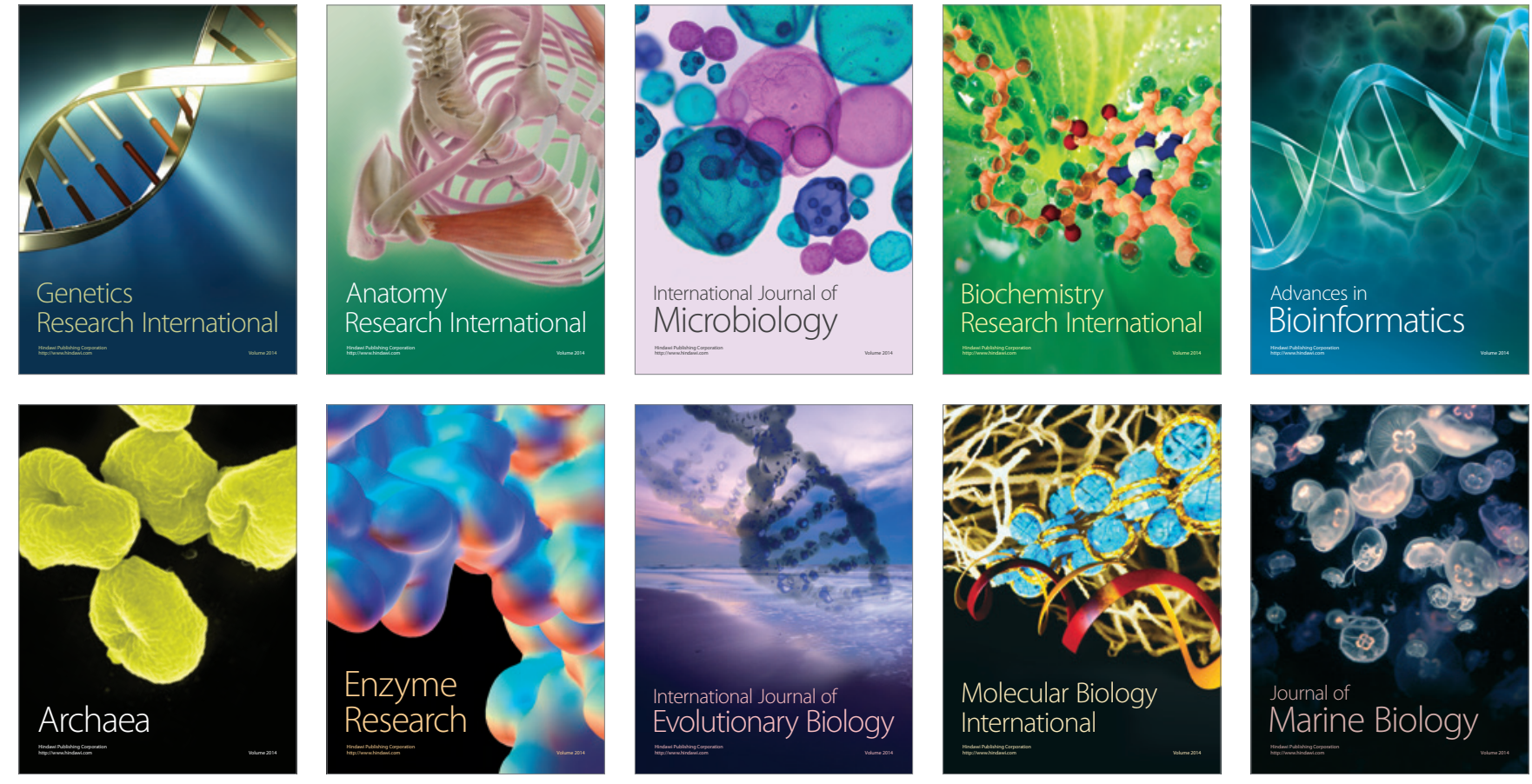